\title{
First record of Prociphilus (Meliarhizophagus) fraxinifolii (Riley) [Hemiptera: Aphididae] in the Iberian Peninsula
}

\author{
N. Pérez Hidalgo and M. P. Mier Durante \\ Departamento de Biodiversidad y Gestión Ambiental, Universidad de León, 24071, León (Spain); e-mail: nperh@unileon.es; \\ mpmied@unileon.es
}

Prociphilus (Meliarhizophagus) fraxinifolii is recorded for the first time on Fraxinus pennsylvanica in Spain. The species, which is of Nearctic origin, is also present in Europe in Hungary (from 2003), Serbia (from 2006) and Bulgaria (from 2007).

On 17 June 2011, spectacular malformations and pseudogalls were observed at the base of a number of Fraxinus pennsylvanica Marsh. plants (Figs 1A-D and 2A,B) in landscaped areas in two localities in León province [León $\left(42^{\circ} 36^{\prime} 50^{\prime \prime} \mathrm{N} / 5^{\circ} 34^{\prime} 1^{\prime \prime} \mathrm{W}\right)$ and Valdeviejas [León $\left.\left(42^{\circ} 27^{\prime} 48^{\prime \prime} \mathrm{N} / 6^{\circ} 4^{\prime} 39^{\prime \prime} \mathrm{W}\right)\right]$. They had been caused by apterae and alatae viviparae from a pemphigine species which, after being studied, were identified as belonging to the Nearctic species Prociphilus (Meliarhizophagus) fraxinifolii (Riley, 1879). This is the first record of the species in the Iberian Peninsula and the fourth in Europe (Coeur d'acier et al., 2010). The samples are deposited in the Zoological Collection (CZULE) of the University of León.

In Europe, another two species of Prociphilus live on species of Fraxinus: Prociphilus (Prociphilus) bumeliae (Schrank, 1801) and Prociphilus (Prociphilus) fraxini (Fabricius, 1777). Their primary host is $F$. excelsior and their secondary host species are Abies spp., on which they are radicolous. They can be identified using the descriptions and keys by Smith (1974), Heie (1980) and Blackman \& Eastop (1994). To date, only three species from the genus Prociphilus have been recorded in the Iberian Peninsula: P. (Prociphilus) fraxini, P. (Prociphilus) oleae (Leach) and $P$. (Stagona) pini (Burmeister), with morphological data and keys (Pérez Hidalgo \& Nieto Nafría, 2003) for their identification.

The genus Prociphilus Koch contains around 50 species grouped into six subgenera: Prociphilus, Meliarhizophagus Smith, Neoparacletus Strom, Paraprociphilus Mordvilko, Pulvius Sanborn and Stagona (Koch). These aphids vary considerably in size, ranging from the rather small P. (Stagona) pini to the very large $P$. (Prociphilus) fraxini, with fully developed waxy plates on the head, thorax and abdomen and with or without porifom siphunculi. The median vein of the anterior wings of the alatae is simple and the secondary sensoria ciliate. Although details of the biology of some species are not known, available data suggest that they are mostly dioecious, their primary host being certain species of Oleaceae, Caprifoliaceae, Aceraceae and Rosaceae, and the secondary host plants from various families on which they are radicolous (Pérez Hidalgo \& Nieto Nafría, 2003). The only species in the subgenus Meliarhizophagus is P. (Meliarhizophagus) fraxinifolii which, according to Blackman \& Eastop (1994), is holocyclic monoecious on
American species of Fraxinus: F. nigra, F. pennsylvanica, $F$. quadrangulata, $F$. sambucifolia, $F$. uhdei and $F$. velutina.

Prociphilus fraxinifolii apterae viviparae (Fig. 2C) are 2.3-3.0 $\mathrm{mm}$ long and yellowish-green to pale green under the filamentous layer of wax covering them. The fundatrices have five antennal segments and eyes formed only by the triommatidium. The apterous fundatrigenae have six antennal segments and several ommatidia, as well as the triommatidium (Fig. 2E). The alatae viviparae (Fig. 2D) are 1.4-2.8 $\mathrm{mm}$ long (3.3-5.20 in P. fraxini), with a greenish-orange abdomen in life due to the yellowish colour of the embryos inside; they also have two pairs of cereous plates in the anterior region of the head and a well defined pair in the posterior area (Fig. 2F) and 1-5 irregular secondary sensorial rhinaria at the base of antennal segment VI.

Colonies are formed by apterae and alatae that curl terminal leaves (Figs 1A,-C and 2A,B). Little is known about the biology of the species, but according to Smith (1974) the alatae viviparae reproduce continuously from April to October and the alate sexuparae from October to November, though in the studied collections, alatae did not occur from mid-August. During the unfavourable season they live in roots and are ant-attended (Smith, 1974).

Despite the spectacular malformations and large quantity of honeydew excreted (Fig. 1E) by these aphids, they do not seem to cause any significant harm to trees, though the leaves they colonize frequently dry prematurely (Fig. 1F). The species is not ant-attended, at least in the aerial part of the plant, and is strongly predated by Anthocoris nemoralis (Fabricius, 1794) (Hemiptera: Anthocoridae) and Chamaemyiidae larvae (Diptera).

This is a common species, widely distributed in the United States, Canada and Mexico (Smith \& Parron, 1978; Peña Martínez, 1985; Maw et al., 2000) and introduced in Chile (Carrillo, 1977), South Africa (Müller \& Schöll, 1958; Blackman \& Eastop, 1994) and Europe (Coeur d'acier et al., 2010). Since it was discovered in Hungary (Remaudière \& Ripka, 2003) it has been recorded in Serbia in 2006 (Petrović-Obradović et al., 2007) and in Bulgaria in 2007 (Trenchev \& Trencheva, 2009), though it is potentially more widely distributed in Europe due to the use of its host plant ( $F$. pennsylvanica) in gardening, which according to Remaudière \& Ripka (2003) was introduced in 1783. 

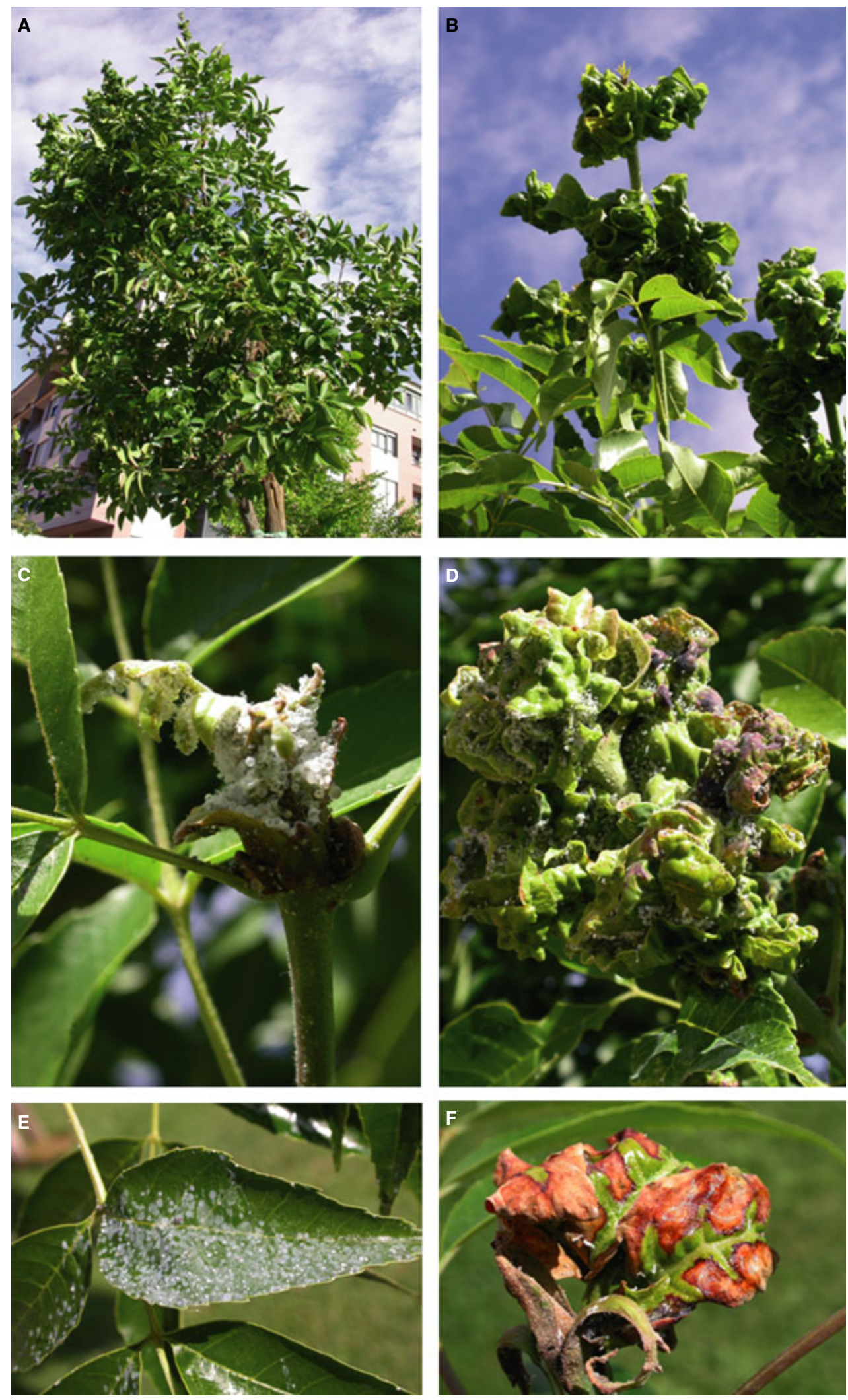

Fig. 1 Malformations or pseudogalls caused by Prociphilus (Meliarhyzophagus) fraxinifolii on Fraxinus pennsylvanica (A-D); honeydew excreted on a leaf (E); and prematurely dried shoots (F). 

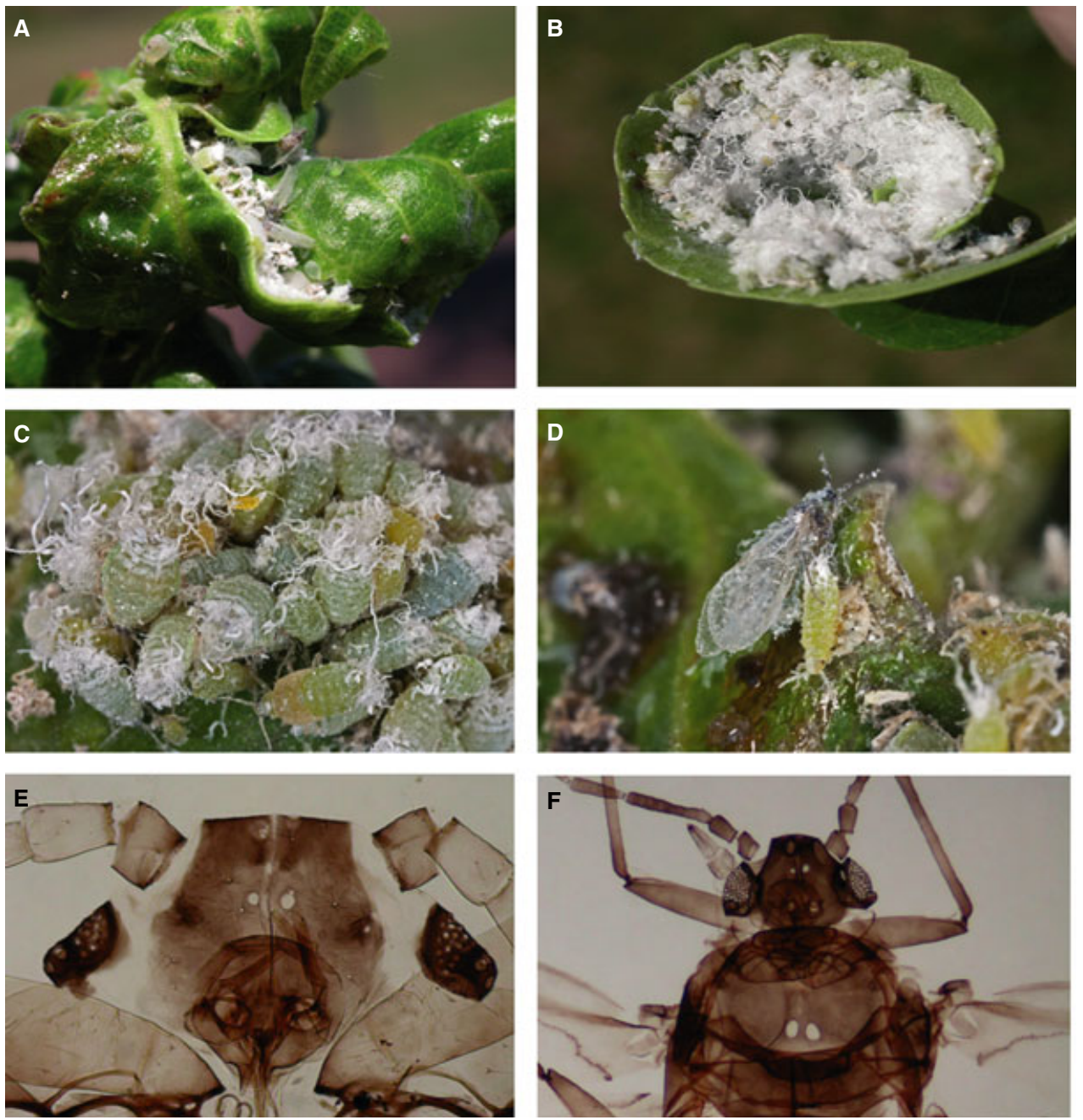

Fig. 2 Malformations caused by Prociphilus (Meliarhyzophagus) fraxinifolii on a shoot (A) and a Fraxinus pennsylvanica leaf (B). Colony of apterae viviparae and nymphs with and without wing sketches (C); alate viviparous female (D); head of the apterous viviparous female (E); and head and thorax of the alate viviparous female (F). Photos C and D by Ángel Umaran.

\section{Acknowledgements}

The authors wish to thank M Baena (Departamento de Biología y Geología, I.E.S. Trassierra, Córdoba, Spain) for identifying the bug species associated with the colonies; C Favret (AphidNet, USA) for sending several references; and the Councils of León and Astorga for their cooperation during the sampling periods. This study was carried out in the context of the 'Fauna Ibérica IX' Project (CGL2007-66786-C08-03).

\section{Premier signalement de Prociphilus (Meliarhizophagus) fraxinifolii (Riley) [Hemiptera: Aphididae] dans la péninsule Ibérique}

Prociphilus (Meliarhizophagus) fraxinifolii est signalé pour la première fois sur Fraxinus pennsylvanica en Espagne. Cette espèce, qui est d'origine néartique, est également présente en Europe en Hongrie (depuis 2003), Serbie (depuis 2006) et Bulgarie (depuis 2007).

\section{Первое обнаружение Prociphilus (Meliarhizophagus) fraxinifolii (Riley) [Hemiptera: Aphididae] на Пиренейском полуострове}

В Испании тля Prociphilus (Meliarhizophagus) fraxinifolii была впервые зарегистрирована на Fraxinus pennsylvanica. Этот вид, имеющий неарктическое происхождение, также присутствует в Европе. В Венгрии - с 2003 года, в Сербии - с 2006 года и в Болгарии - с 2007 года.

\section{References}

Blackman RL \& Eastop VF (1994) Aphids on the World's Trees. An Identification and Information Guide, $8+987$ pp. + 16 pl. CAB International, Wallingford (UK).

Carrillo RL (1977) Aphidoidea de Chile II. Agro Sur 5, 109-114.

Coeur d'acier A, Pérez Hidalgo N \& Petrović-Obradović O (2010) Aphids (Hemiptera, Aphididae). Chapter 9.2. In Alien Terrestrial Arthropods of 
Europe (Eds Roques A, Kenis M, Lees D, López-Vaamonde C, Rabitsch W, Rasplus J-Y \& Roy D). BioRisk 4, 435-474. doi: 10.3897/biorisk.4.57.

Heie OE (1980) The Aphidoidea (Hemiptera) of Fennoscandia and Denmark. I General part. The families Mindaridae, Hormaphididae, Thelaxidae, Anoeciidae, and Pemphigidae. Fauna Entomologica Scandinavica 9, $1-236$.

Maw HEL, Foottit RG, Hamilton KGA \& Scudder GGE (2000) Checklist of the Hemiptera of Canada and Alaska, pp. 220. NRC Research Press, Ottawa (CN).

Müller FP \& Schöll SE (1958) Some notes on the aphid fauna of South Africa. Journal of the Entomological Society of Southern Africa 21 , 382-414.

Peña Martínez R (1985) Ecological notes on aphids of the High Plateau of Mexico, with a check-list of species collected in 1980. in: Proceedings of the International Aphidological Symposium at Jablonna, 1981, pp. 425-430. Wydawnictwo. Wroclaw 510.

Pérez Hidalgo N \& Nieto Nafría JM (2003) Subfamilia Eriosomatinae Kirkaldy, 1905 (1843). En Hemiptera, Aphididae II. Nieto Nafría JM, Mier Durante MP, Binazzi A \& Pérez Hidalgo N (ed. Ramos MA, Alba Tercedor J, Bellés i Ros X, Gosálbez i Noguera J, Guerra Sierra A, Macpherson
Mayol E, Martín Piera F, Serrano Marino J \& Templado González J) Fauna Ibérica, Vol. 19, pp. 141-275. Museo Nacional de Ciencias Naturale, CSIC Madrid (ES) [2002]. (in Spanish).

Petrović-Obradović O, Tomanović Ž, Poljaković-Pajnik L \& Vučetić A (2007) An invasive species of aphid, Prociphilus fraxinifolii (Hemiptera, Aphididae, Eriosomatinae), found in Serbia. Archives of Biological Sciences, Belgrade 59, 9-10.

Remaudière G \& Ripka G (2003) Arrival in Europe (Budapest, Hungary) of American ash aphid, Prociphilus (Meliarhizophagus) fraxinifolii (Hemiptera, Aphididae, Eriosomatinae, Pemphigini). Revue Francaise d'Entomologie (N.S.) 25, 152

Smith CF (1974) Keys and descriptions of the genera of Pemphigini in North America (Homoptera: Aphididae: Pemphigini). North Carolina Experiment Station, Technical Bulletin 226, vi +61 .

Smith CF \& Parron CS (1978) An annotated list of Aphididae (Homoptera) of North America. North Carolina Agricultural Experiment Station, Technical Bulletin 255, $8+428$.

Trenchev G \& Trencheva K (2009) Prociphilus fraxinifolii Riley (Hemiptera, Aphididae, Eriosomatinae) a species new to the Bulgarian fauna. Journal of Sustainable Forestry, 59-60, 79-82. 